\author{
Ewa KORCELLI-OLEJNICZAK \\ Dr hab., prof. IGiPZ PAN, Instytut Geografii i Przestrzennego Zagospodarowania, Polska Akademia Nauk, Warszawa \\ eko@twarda.pan.pl \\ Piotr DWORZAŃSKI \\ Mgr, Instytut Socjologii, Uniwersytet Warszawski \\ dworzanskip@gmail.com \\ Filip PIOTROWSKI \\ Mgr, Instytut Geografii i Przestrzennego Zagospodarowania, Polska Akademia Nauk \\ piotrowski@twarda.pan.pl
}

\title{
HIPERRÓŻNORODNOŚĆ LOKALNIE: MOBILNOŚĆ SPOŁECZNA I ROZWÓJ PRZEDSIĘBIORCZOŚCI NA PRADZE-PÓŁNOC W WARSZAWIE
}

\begin{abstract}
Abstrakt: Artykuł opisuje proces gentryfikacji na Pradze-Północ, który prowadzi do hiperróżnorodności tej dzielnicy. Badania pokazują, że zróżnicowanie społeczne może mieć zarówno pozytywny, jak i negatywny wpływ na mobilność społeczną, choć żeby uruchomić jego potencjał do pozytywnych zmian, ważne jest wcześniejsze zadbanie o integrację społeczną w danym regionie. Hiperróżnorodność ma także dwojaki wpływ na przedsiębiorczość na Pradze. Z jednej strony obniża próg wejścia, ułatwiając założenie biznesu, który jest w stanie się utrzymać, ale jednocześnie znacząco utrudnia wytworzenie szerokiego grona stałej klienteli, która dawałaby przedsiębiorcom poczucie stabilności i możliwość rozwoju.

Słowa kluczowe: hiperróżnorodność, gentryfikacja, mobilność społeczna, przedsiębiorczość, Praga-Północ, Warszawa.
\end{abstract}

\section{INFLUENCE OF HYPER-DIVERSITY AND GENTRIFICATION ON SOCIAL MOBILITY AND ECONOMIC PERFORMANCE IN PRAGA-PÓENOC IN WARSAW}

\begin{abstract}
The paper discusses the ongoing process of early-stage gentrification in Praga-Północ, that leads to the hyper-diversity of this area. Our study shows that diversity can play as well as a positive and negative role in fostering the area's social mobility. A factor stimulating the process is social integration which should be simultaneously achieved. Hyper-diversity also has an impact on the area's economic performance. Our findings show that, while generally, the establishment of a business activity is easier in such conditions due for example to low barriers to entry or the presence of a diverse clientele, firms functioning in diverse areas are less economically sustainable.

Keywords: hyper-diversity, gentrification, social mobility, entrepreneurship, Praga-Północ, Warsaw.
\end{abstract}

\section{WSTĘP}

Miasta są obszarami z definicji niezwykle zróżnicowanymi społecznie, a jednocześnie charakteryzującymi się długim okresem trwania. Procesy historyczne w większości przypadków wzmacniały jeszcze tendencje do dehomogenizacji mieszkańców, generując w przestrzeni miejskiej barwne hiperróżnorodne skupiska ludzkie. Zróżnicowanie geograficzne i infrastrukturalne nakłada się tu na procesy społeczne, prowadząc do powstania tak zróżnicowanych obszarów, jak: enklawy dla bogatych, slamsy i getta dla najuboższych, przedmieścia klasy średniej, zamknięte społeczności, tereny o kurczącej się lub o rosnącej populacji ze względu na procesy imigracyjne populacji. Różne osiedla mieszkaniowe zachowują homogeniczny charakter, stając się enklawami poszczególnych klas społecznych lub grup etnicznych - bądź stają się heterogenicznymi obszarami mieszania się wpływów, kultur i aspiracji osób o zróżnicowanym statusie klasowym. Trzeba jed- nak dodać, że zróżnicowanie to, poza „twardymi” wskaźnikami, takimi jak dochód, wykształcenie, pochodzenie etniczne, rasa czy struktura gospodarstw domowych, we współczesnej przestrzeni miejskiej coraz częściej opiera się na „miękkich” cechach, takich jak styl życia, postawy i rodzaje aktywności. Na obszarach miejskich nie zawsze dochodzi jednak do bezpośrednich intensywnych kontaktów silnie różniących się od siebie mieszkańców. Alternatywą staje się zamieszkiwanie „obok siebie”, bezrefleksyjne mijanie się na ulicach, przebywanie w zamkniętych, ogrodzonych przestrzeniach chroniących swych mieszkańców przed kontaktem z „innymi”. Wspólne zamieszkiwanie, niezależnie od tego, jaką przyjmie formę, może prowadzić zarówno do względnie harmonijnego współżycia, jak i do generowania napięć przeradzających się czasem w otwarte konflikty pomiędzy poszczególnymi grupami mieszkańców. 
Niniejszy artykuł składa się z pięciu części. W pierwszej omówiono podstawowe pojęcia, takie jak „zróżnicowanie społeczne”, „super- i hiperróżnorodność, „mobilność społeczna” oraz „gentryfikacja”, a także przedstawiono literaturę związaną z tematem. Część druga zawiera charakterystykę socjologiczną Warszawy oraz Pragi-Północ jako obiektu badań. W części trzeciej przedstawiono wpływ hiperróżnorodności i gentryfikacji na mobilność społeczną na Pradze-Północ w Warszawie, a w czwartej - wpływ tych czynników na rozwój ekonomiczny badanego obszaru. Wyniki prezentowane w częściach trzeciej i czwartej uzyskano $\mathrm{w}$ efekcie badań realizowanych $\mathrm{w}$ dzielnicy Praga-Północ w ramach 7 PR UE Divercities ${ }^{1}$. W części piątej podsumowano wyniki badań.

\section{PODSTAWY TEORETYCZNE I OPERACJONALIZACJA POJĘĆ}

W opracowaniach socjologicznych „zróżnicowanie” definiowane jest jako wspótistnienie pewnej liczby specyficznych socjoekonomicznych, socjodemograficznych, etnicznych i kulturowych grup na określonym obszarze, takim jak miasto lub osiedle. W niniejszej pracy chcemy sprecyzować, w jaki sposób zróżnicowanie oddziałuje na mobilność społeczną oraz wydajność ekonomiczną przedsiębiorców. Wspomniana „mobilność społeczna” odnosi się do możliwości indywidualnych osób lub grup do poruszania się w górę lub w dół drabiny społecznej, np. w związku z pracą, zarobkami, statusem lub władzą, a „wydajność ekonomiczna przedsiębiorców" związana jest z wynikami, jakie osiągają indywidualni przedsiębiorcy lub grupy $\mathrm{w}$ danym mieście.

Ukuty przez S. Vertoveca (2007) termin „superróżnorodność" odnosi się do specyfiki zachodnich miast polegającej na ich rosnącym zróżnicowaniu etnicznym oraz demograficznym, a także socjoekonomicznym z pomiędzy i wewnątrz tych grup. S. Vertovec (2007, s. 1024) mówi o „dynamice zmiennych wśród rosnącej liczby nowych grup imigrantów, którzy napłynęli w ciągu ostatniej dekady, małych i rozproszonych, o zróżnicowanym pochodzeniu, połączonych transnarodowo, zróżnicowanych socjoekonomicznie i rozwarstwionych". Tym samym S. Vertovec zauważa olbrzymie zróżnicowanie wewnątrz kategorii imigrantów.

Idziemy o krok dalej i zamierzamy stosować pojęcie „hiperróżnorodność”. Termin ten odnosi się nie tylko do zróżnicowania w rozumieniu etnicznym, demograficznym i socjoekonomicznym, lecz także do różnic związanych ze stylami życia, światopoglądem i rodzajami aktywności. Tego typu zróżnicowanie jest istotne przy wyjaśnianiu zjawisk takich, jak spójność lub mobilność społeczna. Ludzie należący do tej samej grupy społecznej lub etnicznej mogą wykazywać różne nastawienia wobec szkoły, pracy, rodziców lub innych grup. Mogą mieć bardzo odmienne plany dnia. Niektórzy mogą przejawiać wzory intensywnej mobilności, codziennie podróżując po całym mieście i poza nim, podczas gdy inni spędzają większość czasu w obrębie swojego osiedla. Obszar codziennych interakcji autochtonicznego mieszkańca może być ograniczony do najbliższego otoczenia, a jego cudzoziemski sąsiad może być znacznie bardziej mobilny w związku z zajęciami zawodowymi lub na odwrót.

Hiperróżnorodność odnosi się zatem do intensywnego zróżnicowania populacji zarówno w rozumieniu socjoekonomicznym, społecznym oraz etnicznym, jak i w odniesieniu do stylów życia, światopoglądu i aktywności (Tasan-Kok i in. 2014). Zastosowanie tego określenia zakłada szerokie spojrzenie na kwestie zróżnicowania społecznego w mieście. Hiperróżnorodność odnosi się zatem do znacznie szerszego spektrum dywersyfikacji niż superróżnorodność, ponieważ zakłada się więcej zmiennych, co prowadzi do bardziej skomplikowanych zależności między tymi zmiennymi. Używając terminu „hiperróżnorodność” bierze się np. pod uwagę fakt, że grupa biednych, młodych mężczyzn indyjskiego pochodzenia, żyjących w Londynie może na pierwszy rzut oka tylko wydawać się bardzo homogeniczna. Jednak przypatrzywszy się jej bliżej można zauważyć, że jest jednak silnie heterogeniczna. Niektórzy z tej grupy chętnie oglądają sport w telewizji w domu, inni skupiają się głównie na intensywnych kontaktach z rodziną i przyjaciółmi w Indiach (przez maile, Skype, Facebooka, Twittera, Instagrama etc.), a inni zwykle przesiadują na osiedlowym placu, gdzie nawiązują znajomości z autochtonicznymi mieszkańcami Londynu.

Hiperróżnorodne miasto zawiera wciąż zmieniające się i przybywające wymiary zróżnicowania. Zgodnie z literaturą, nowe formy zróżnicowania są rezultatem wielu czynników, takich jak: zwiększająca się sieć migracji i zróżnicowania krajów pochodzenia (Vertovec 2007), rosnąca mobilność społeczna (Syrett, Sepulveda 2007, 2011), dynamiczna natura migracji globalnych, nowe formacje społeczne w miastach i zmieniające się warunki oraz pozycja imigrantów i mniejszości etnicznych $\mathrm{w}$ środowisku miejskim (Vertovec 2010), połączenie transnarodowe, lecz zróżnicowanie socjoekono- 
miczne i rozwarstwienie imigrantów (Vertovec 2007), nowe struktury władzy i polityki oraz dynamiczne tożsamości (Cantle 2012), rosnąca heterogeniczność migracji, różnicująca się w takich aspektach, jak kraj pochodzenia, etniczność, grupy narodowe, religia, język, kanał migracyjny czy status legalności migracji (Faist 2009). Neoliberalne deregulacje, które są pożywką dla zróżnicowania przez ostatnie 30 lat, na kilka sposobów (globalizacja ekonomiczna, wzrost nierówności płac, polaryzacja, segregacja, etc.) wpływają na wzrost zróżnicowania społeczeństwa miejskiego.

Gentryfikacja jest jednym z najważniejszych czynników różnicujących społeczeństwo. Zdefiniowaliśmy ją jako proces reinwestycji kapitału, poprawę statusu socjoekonomicznego osiedla, zmianę krajobrazu miejskiego oraz pośrednie lub bezpośrednie wsparcie dla uboższych mieszkańców przez bogatsze grupy (Davidson, Lees 2005). W krajach postsocjalistycznych proces ten może być inicjowany przez pionierów, np. artystów, studentów, młode gospodarstwa domowe (Grabkowska 2012, Kovács, Wiesner, Zischner 2013), a także przez deweloperów (Badyina, Golubchikov 2005).

Mobilność społeczna odnosi się do możliwości osób lub grup do poruszania się w górę lub w dół drabiny społecznej, np. w związku z różnicami w wykonywanym zawodzie, dochodach czy statusie społecznym lub w hierarchii władzy. Bywa definiowana na wiele sposobów, zarówno wąsko jak i szeroko. W niemal wszystkich definicjach pojawia się sformułowanie kariery zawodowej. Jednostki są mobilne społecznie, kiedy zmieniają pracę lub przechodzą z bezrobocia do aktywności zawodowej i na odwrót. Mówiąc o mobilności społecznej należy przykładać szczególną wagę do pojęcia kapitału społecznego. W najprostszym rozumieniu kapitał społeczny odnosi się do potencjalnych profitów, które można odnieść z kontaktów społecznych (Kleinhans 2005). Tworzy się w ten sposób połączenie między spójnością a mobilnością społeczną. Dla P. Bourdieu'a i L.J.D. Wacquanta kapitał społeczny jest zasobem lub relacją władzy, którą jednostki osiągają poprzez społeczne sieci i powiązania: „Kapitał społeczny jest sumą zasobów, rzeczywistych lub wirtualnych, jakie przepływają między jednostkami lub grupami dzięki posiadaniu trwałych sieci mniej lub bardziej zinstytucjonalizowanych relacji wzajemnej znajomości i rozpoznawalności” (Bourdieu, Wacquant 1992, s. 119). Ta definicja skupia się na faktycznych zasobach, które jednostki lub grupy mogą posiąść, które pomogą im osiągać cele, np. znaleźć pracę lub kupić dom.
Kluczowe staje się pytanie, w jaki sposób jednostki mogą czerpać zyski z kontaktów społecznych? Zależnie od rodzaju kontaktów możemy wyróżnić wiedzę praktyczną lub istotne informacje. W literaturze występuje ważne rozróżnienie na kapitał spajający (bonding capital) $\mathrm{z}$ jednej strony oraz kapitał pomostowy (bridging capital) z drugiej (Granovetter 1973, Putnam 2001). Kapitał spajający odnosi się do silnych więzi wewnątrz grupy społecznej (podobni inni - similar others), podczas gdy kapitał pomostowy łączy osoby $\mathrm{z}$ różnych grup społecznych (słabe więzi - weak ties). Ten drugi rodzaj kapitału ma większe szanse na przyniesienie kluczowych informacji związanych np. z możliwościami zatrudnienia (Granovetter 1973). W naszym badaniu postrzegamy kapitał społeczny jako zasób dla mobilności społecznej. Innymi słowy, może on zostać użyty, aby uzyskać pożądaną mobilność społeczną. Tym samym kapitał społeczny nie jest tożsamy z mobilnością społeczną.

$\mathrm{W}$ badaniach na temat efektu wpływu sąsiedztwa relacja między charakterystyką sąsiedztwa, a mobilnością społeczną jest zagadnieniem kluczowym. W wielu opracowaniach, wpływ segregacji (zwykle etnicznej lub związanej z przychodem) na mobilność społeczną jest uważany za ważniejszy od wpływu zróżnicowania. Typowy kwestionariusz zawiera określone pytania (Friedrichs 1998), takie jak: czy życie w osiedlu zdominowanym przez pewien typ ludzi ogranicza mobilność społeczną?, czy życie w osiedlu etnicznym zmniejsza szanse na integrację i asymilację?, czy zubożałe dzielnice dostarczają mniej możliwości znalezienia pracy dla ich mieszkańców? Można podać konkretne rezultaty studiów nad efektem sąsiedztwa. Studia nad efektem zróżnicowania dochodowego w Szwecji, przeprowadzone na dorosłych osobach (Galster 2008), pokazały, że efekty sąsiedztwa istnieją, ale są stosunkowo małe. S. Urban (2009) wskazuje tylko na małe efekty sąsiedztwa wpływające na osiedla w Sztokholmie, w których są dzieci i które to osiedla są zróżnicowane pod względem dochodu i ryzyka bezrobocia. L. Brännström i Y. Rojas (2012) również uzyskali mieszane rezultaty badając efekty życia w osiedlach zamieszkanych przez relatywnie duże grupy mniejszości etnicznych na efekty w nauce. I.R. Gordon i V. Monastiriotis (2006) wskazują na efekt wpływu sąsiedztwa na wyniki w nauce w przypadku grup poszkodowanych - a jednocześnie na bardziej pozytywne efekty segregacji w przypadku gospodarstw domowych klasy średniej. Z każdego z tych badań wynika, że charakterystyka indywidualna jest znacznie bardziej istotna dla mobil- 
ności społecznej niż charakterystyka osiedla, przynajmniej w miastach europejskich.

Dlaczego efekt wpływu sąsiedztwa na różne aspekty życia jest tak mały? Może to być najprawdopodobniej związane $\mathrm{z}$ faktem, że życie ludzi nie jest w pełni zorganizowane wokół domu i jego sąsiedztwa. Wraz z rozwojem technologii, lepszymi środkami transportu i niemal nielimitowanymi możliwościami kontaktu dzięki Internetowi i urządzeniom mobilnym, ludzie biorą teraz udział $\mathrm{w}$ licznych sieciach, odwiedzając wiele miejsc i spotykając różnych ludzi, zarówno fizycznie jak i wirtualnie (Van Kempen, Wissink 2014). Mieszkańcy mogą mieć kontakty w całym mieście, a grupy (także etniczne) mogą tworzyć sieci z ludźmi na całym świecie (Zelinsky, Lee 1998), w swojej okolicy, w swoim kraju pochodzenia, gdzie ciągle może żyć duża część ich rodziny i znajomych, i także w dowolnej części świata, gdzie żyją bliscy im ludzie (Bolt, Van Kempen 2013).

W literaturze poświęconej studiom miejskim możemy przede wszystkim znaleźć połączenie zróżnicowania w mieście $\mathrm{z}$ jego dobrymi osiągnięciami ekonomicznymi. S. Fainstein (2005, s. 4) pisze np.: „,szanse na rozwój konkurencyjności miasta, czyli najbardziej kuszące podejście żeby osiągnąć sukces ekonomiczny, leżą w rozwoju zróżnicowania społeczeństwa, bazy ekonomicznej oraz środowiska fizycznego." Z tego szeroko akceptowanego punktu widzenia zróżnicowanie społeczne jest istotnym zasobem dla dobrobytu miasta, a wielu innych badaczy widzi też $\mathrm{w}$ nim potencjalny katalizator rozwoju socjoekonomicznego (Bodaar, Rath 2005, Eraydin, Tasan-Kok, Vranken 2010, Tasan-Kok, Vranken 2008). Jednak zdarzają się przedsiębiorcy, którzy odnieśli sukces, mieszkając w homogenicznych okolicach. Niektórzy naukowcy twierdzą, że nie istnieje pozytywna korelacja między osiągnięciami ekonomicznymi a zróżnicowaniem miasta $\mathrm{z}$ socjologicznego punktu widzenia (Angrist, Kugler 2003, Alesina, La Ferrara 2005). Jednak najpowszechniejsza jest opinia, że zróżnicowanie to ma pozytywny wpływ na rozwój ekonomiczny miast.

\section{WARSZAWA I PRAGA-PÓŁNOC}

Warszawa, opisywana $\mathrm{w}$ niniejszym artykule, jest zróżnicowanym społecznie miastem, o populacji około 1735442 osób. Jako stolica Polski i największe miasto w kraju pełni ważne funkcje administracyjne, kulturalne i ekonomiczne. Przez stulecia obok polsko- języcznych katolików była zamieszkana przez wiele mniejszości, m.in. przez Żydów, Niemców i Rosjan. W związku ze zmianami spowodowanymi drugą wojną światową zróżnicowanie etniczne przedwojennej Warszawy ustąpiło miejsca kulturowej homogeniczności.

Obszar, na którym zostało przeprowadzone nasze badanie - Praga-Północ, jest jedną z 18 dzielnic Warszawy. Charakteryzuje się dużą różnorodnością społeczno-ekonomiczną oraz społeczną deprywacją. Jednocześnie jest to miejsce dynamiczne w związku z trwającą tam gentryfikacją - obserwowanym ostatnio napływem ludności o wyższym dochodzie oraz wyższym wykształceniu. Fenomen ten, zwany często „modą na Pragę", jest stymulowany relatywnie niskimi cenami mieszkań, nowymi inwestycjami publicznymi i prywatnymi, realizowanymi od kilku lat programami rewitalizacji, a także specyficzną atmosferą, oferowaną przez miejscowy folklor (por. Korcelli-Olejniczak i in. 2015, Korcelli-Olejniczak, Piotrowski 2015). Ze swoimi przedwojennymi tradycjami zróżnicowania etnicznego, Praga jest dziś obszarem silnie zróżnicowanym społecznie, gdzie nowi mieszkańcy (często przedstawiciele klasy kreatywnej) żyją wespół ze starymi mieszkańcami tutejszych osiedli. Praga-Północ jest obszarem, gdzie bieda, dysfunkcja, lokalny klimat i tradycja spotyka się z dynamicznym rozwojem metropolitalnym, reprezentowanym m.in. przez nowe Centrum Praskie „Koneser”, z campusem Google. W związku z tymi zmianami, Praga staje się dla turystów coraz bardziej interesującym miejscem (Korcelli-Olejniczak $i$ in. 2016, Derek i in. 2013).

Zróżnicowanie Warszawy jest fenomenem jednocześnie nowym i starym. Przez całą swoją historię, Warszawa doświadczała różnych zmian tkanki miejskiej, struktury społecznej oraz kompozycji społecznej. Heterogeniczna etnicznie przedwojenna metropolia (1918-1939) przekształciła się w etnicznie homogeniczną stolicę kraju socjalistycznego po 1945 r. Począwszy od 1989 r. Warszawa buduje swoją pozycję jako lider socjoekonomicznej transformacji w Europie Środkowo-Wschodniej. Dynamiczny rozwój i globalizacja przyczyniły się do szybkich zmian na wielu poziomach, co dało impuls do wzrostu zróżnicowania w mieście (Korcelli-Olejniczak $i$ in. 2014).

Co może zwrócić uwagę zewnętrznego obserwatora, to zaskakująco niski poziom zróżnicowania etnicznego w Warszawie. Na pierwszy rzut oka wydaje się ona miastem niezwykle homogenicznym. Jest to $\mathrm{w}$ dużej mierze związane z faktem, że Polska jest najmniej zróżnicowanym etnicznie krajem w całej Unii Euro- 
pejskiej. W skali kraju Warszawa jest największym magnesem zarówno dla migracji wewnętrznych, jak i zewnętrznych ${ }^{2}$. Niemniej, jeśli ją porównać z dużymi miastami tzw. starej Unii Europejskiej, zróżnicowanie etniczne i kulturowe jest bardzo małe. Zgodnie z ostatnimi danymi, w Warszawie przez okres dłuższy niż trzy miesiące żyje około 50000 cudzoziemców, czyli mniej niż 3\% całej populacji miasta (Winiarska 2014). Nie pozwala nam to jednak zidentyfikować Warszawy jako miasta nieróżnorodnego. Samo sedno różnorodności leży bowiem w pojęciu miejskich podziałów (urban divisions) (por. Bridge, Watson 2013, s. 500), odnoszącym się do klasy, ekonomii, statusu społecznego, płci biologicznej i społecznej, wieku, niepełnosprawności i afiliacji religijnej.

Warszawa przyciąga imigrantów z różnych części Polski z powodów ekonomicznych i społecznych. Jest to związane z jej dynamicznym i zróżnicowanym rynkiem pracy oraz z otwartym, tolerancyjnym i metropolitalnym charakterem tej metropolii w porównaniu z innymi miastami Polski (Łukasiuk 2007). Istnieją dwa podstawowe modele tego typu migracji. Pierwszy z nich związany jest ze „stałą nowoczesnością”, opartą o tradycyjne wartości (takie jak stabilność, praca, rodzina, kariera), podczas gdy drugi powiązany jest z szukaniem „płynnej nowoczesności”, którą oferuje miasto (Bauman 2000). Te dwa modele korespondują także z rosnącym pluralizmem społecznym, opartym o style życia, światopoglądy i opinie. Obok zróżnicowania demograficznego, wykształca się także nowa dychotomia społeczna: tradycyjne gospodarstwa domowe przenoszą się na przedmieścia, podczas gdy nowoczesne życie miejskie toczy się w Śródmieściu.

Współczesna Warszawa jest miejscem licznych zmian przestrzennych. Środek miasta zmienia się w dzielnicę biznesową, pojawia się nowa infrastruktura transportowa (łącznie z drugą linią metra) oraz coraz więcej obszarów zieleni tak w centrum, jak i na obrzeżach. Wraz z dywersyfikacją funkcjonalnej przestrzeni Warszawa traci charakter miasta postsocjalistycznego i nabywa uniwersalnych standardów nowoczesnego rozwoju miejskiego. Pod wieloma względami przestaje przypominać miasto znane jego mieszkańcom przed 1989 r. Mimo ciągle marginalnej roli, jaką odgrywają etniczni imigranci, wzory przekształceń społeczno-przestrzennych stają się coraz bardziej podobne do tych obserwowanych w innych europejskich miastach. Rośnie segregacja społeczno-przestrzenna, odnosząca się do sytuacji ekonomicznej, statusu zawodowego i wieku, choć nadal jest niezauważalna gołym okiem.
Warszawa staje się coraz bardziej kosmopolityczna, a jej mieszkańcy wykazują zróżnicowane style życia, poglądy i wartości. Oferta usług rekreacyjnych, kulturalnych, kulinarnych i religijnych, oferowanych przez firmy, organizacje i instytucje, ciągle rośnie, podobnie jak oferta usług publicznych skupionych na klientach międzynarodowych. Prywatne międzynarodowe szkoły, przedszkola i żłobki mnożą się w całym mieście, a władze miasta oferują coraz więcej wsparcia cudzoziemcom w Warszawie. W okresie 2013-2014 r. do warszawskich szkół uczęszczało 1200 uczniów zagranicznego pochodzenia, głównie Wietnamczyków, Ukraińców, Czeczenów, a także Romów (Miasta otwarte 2015). Wraz ze wzrostem liczby takich uczniów, tymczasowych rezydentów i osób dojeżdżających do Warszawy do pracy, miasto staje się coraz bardziej różnorodne i otwarte na różnorodność. Warszawa ma potencjał do wzrostu w najbliższych dziesięcioleciach, w związku ze swoją atrakcyjnością dla migrantów oraz ciągle dużymi rezerwami przestrzeni wewnątrz miasta (Korcelli, Korcelli-Olejniczak 2005). Równocześnie można oczekiwać dalszego różnicowania się mieszkańców w związku ze spodziewanym napływem imigrantów oraz wewnętrznymi zmianami społecznymi w mieście.

Praga-Północ zamieszkana przez około 68000 osób (Rocznik statystyczny Warszawy 2012) jest uważana za najbardziej różnorodną dzielnicę Warszawy zarówno pod względem demograficznym i statusu socjoekonomicznego (Stępniak i in. 2009). Różnorodność ta objawia się zarówno w wymiarze fizycznym, jak i społecznym. Zaniedbane przedwojenne kamienice, będące własnością miasta, sąsiadują z nowymi budynkami prywatnych deweloperów. Na Pradze-Północ daje się zauważyć nadreprezentacja mieszkańców z niższym wykształceniem i osób bezrobotnych (150\% warszawskiej średniej) oraz najwyższy w Warszawie procent ludności korzystającej z zasiłków (200\% warszawskiej średniej). Koncentracja biednych rodzin w tej dzielnicy związana jest z wysokim udziałem budownictwa komunalnego w zabudowie mieszkaniowej. Stanowi on 45\% zabudowy mieszkaniowej Pragi-Północ, podczas gdy dla całej Warszawy odsetek ten wynosi tylko 19\% (Bank Danych Lokalnych GUS 2015). Przedwojenne kamienice stanowiące $\mathrm{w}$ większości mienie komunalne, znajdują się często w bardzo złym stanie technicznym.

Jednocześnie Praga podlega procesowi gentryfikacji związanemu $\mathrm{z}$ niedawnym napływem ludności o stosunkowo wysokim statusie ekonomicznym i z wyż- 
szym wykształceniem. Wraz z transformacją społeczno-ekonomiczną, która przyniosła zmiany demograficzne, ideologiczne i kulturowe, dzielnica stała się miejscem modnym i popularnym, przyciągając imigrantów szukających tanich mieszkań, przedstawicieli klasy kreatywnej, jak również ludzi doceniających miejscowego „ducha”. „Old Praga objawiła się w drugiej połowie lat 90. XX w. jako dzielnica artystów (malarzy, rzeźbiarzy, muzyków, projektantów mody etc.), niecodziennych miejsc $\mathrm{w}$ starych kamienicach, teatrów artystycznych - stała się domeną bohemy. Sztuka rozprzestrzeniła się na prawym brzegu Wisły (powstało m.in. Centrum Artystyczne Fabryka Trzciny)" (Derek i in. 2013). Nowe budownictwo mieszkaniowe oraz komercyjne i infrastrukturalne inwestycje na Pradze-Północ przyciągają migrantów reprezentujących różne style życia i światopoglądy. Procesy te zaczęły zmieniać negatywny obraz Pragi jako dzielnicy uważanej za biedną i niebezpieczną. Powoli staje się miejscem zyskującym na popularności i relatywnie modnym, pozostając jednocześnie tanim miejscem do życia. Charakteryzuje się także dość dużym udziałem mieszkańców, żyjących tu od urodzenia - stanowią oni około $55 \%$ populacji, czyli o 5 punktów procentowych więcej, niż średnia dla Warszawy. Może to być wyjaśnione mniejszą mobilnością mieszkaniową rodzin żyjących w tutejszych mieszkaniach komunalnych. Udział mieszkań komunalnych w rynku mieszkaniowym Pragi jest ponad dwa razy większy niż średnia warszawska. Spora część z nich jest słabo wyposażona i w bardzo złym stanie. Jednocześnie Praga-Północ jest jedną z dwóch dzielnic (drugą jest Śródmieście) charakteryzujących się długoterminowym odpływem mieszkańców netto. Jest to związane głównie z relokacją mieszkańców kamienic, które ze względu na swój zły stan nie mogły być dłużej używane, oraz niską skalą nowych inwestycji mieszkaniowych. Przez cały okres powojenny dzielnica charakteryzowała się depopulacją, podczas gdy miasto jako całość ciągle się powiększało i wzrastała liczba jego ludności. W ostatnich latach $2 / 3$ odpływu ludności z Pragi-Północ związane było $\mathrm{z}$ migracją międzydzielnicową $\mathrm{w}$ obrębie miasta. Niemniej oficjalne statystyki nie biorą pod uwagę dużej liczby niezarejestrowanych migracji wewnątrz miasta, głównie dotyczących młodych ludzi, którzy chętniej wybierają Pragę-Północ jako tanią opcję mieszkaniową. Ogólny negatywny bilans migracji w ostatnich latach wyraźnie osłabł.

\section{HIPERRÓŻNORODNOŚĆ - WYNIKI BADAŃ DIVERCITIES}

Jak wynika z naszych badań, mieszkańcy Pragi wskazują na dwie podstawowe kategorie motywów wyboru tej dzielnicy jako miejsca zamieszkania. Pierwsza z nich jest ekonomiczna, związana ze stosunkowo tanimi możliwościami zamieszkania i dostępnością mieszkań komunalnych, a druga dotyczy motywów rodzinnych i osobistych. Wszystkie pozostałe motywy (jeśli występują) traktowane są jako przesłanki dodatkowe towarzyszące dwu motywom funkcjonalnym lub emocjonalnym. W większości przypadków „starzy” mieszkańcy Pragi zostali ulokowani w tutejszych kamienicach komunalnych lub mieszkaniach służbowych przed 1990 r. lub przenieśli się do nich pośrednio lub bezpośrednio z powodów rodzinnych. Wśród respondentów, którzy przybyli żyć w Warszawie w związku z podjęciem studiów, wybór Pragi-Północ jest ściśle związany z niskimi cenami wynajmu mieszkań.

Autochtoniczni mieszkańcy Pragi podkreślają swoje zakorzenienie (Gusfield 1975) w tej dzielnicy jako najsilniejszy powód pozostawania $\mathrm{w}$ niej, zaraz obok silnych więzi rodzinnych oraz „moralności”, rozumianej jako „niezepsute” środowisko społeczne i prostota codziennego życia. Niektórzy podkreślają jednak, że zmiany zachodzące na Pradze są dla nich niekorzystne, głównie w wymiarze społecznym. Nie spodziewają się poprawy w związku ze zmianami zachodzącymi w ich okolicy. Bardzo nieliczni oczekują pozytywnych skutków z napływu dobrze wykształconych młodych ludzi i bardziej zamożnych mieszkańców. Potencjał związany z różnorodnością społeczną i heterogenizacją dzielnicy jest nieobecny w odpowiedziach „starych” mieszkańców Pragi-Północ, którzy jednak zwracają uwagę na różnorodność architektoniczną i funkcjonalną, wynikającą z gentryfikacji dzielnicy.

W przypadku zamożniejszych mieszkańców, którzy niedawno wprowadzili się na Pragę-Północ, wybór mieszkania w nowo wybudowanych ,apartamentowcach" lub w starych budynkach jest na ogół związany ze stylem życia, typem edukacji, statusem rodziny, zainteresowaniami i generalnymi wartościami, które reprezentują. Artyści, duże rodziny i dobrze wyedukowani „single” preferują „bohemiczną” atmosferę dostarczaną przez stare, przedwojenne budynki z dużymi mieszkaniami, często kompletnie przearanżowanymi przez nowych właścicieli. Młode pary, osoby z jednym 
lub dwojgiem dzieci, ludzie pracujący w zawodach związanych z biznesem i starzejący się profesjonaliści (60+) wybierają zwykle nowe mieszkalnictwo oferowane przez deweloperów, często w małych, ogrodzonych i strzeżonych osiedlach. W przypadku pierwszej grupy, która jest stosunkowo mała, różnorodność, we wszystkich swoich aspektach, jest postrzegana jako naturalny stan rzeczy lub - w niektórych przypadkach - nawet jako czynnik przyciągający na Pragę-Północ. Nie licząc jednak takich nielicznych przypadków, najczęściej to komfort decyduje o wyborze miejsca zamieszkania - bliskość centrum miasta i niskie ceny mieszkań.

Praga-Północ jest dzielnicą, w której koncentrowała się bieda, społeczna deprywacja i dysfunkcje - alkoholizm, przestępczość, bezrobocie (Węcławowicz 2001). Postrzegana była jako dzielnica „wykluczona”. Do niedawna Praga-Północ była uważana za miejsce zaniedbane, gdzie uprzedzenia i brak zainteresowania władz lokalnych doprowadziły do regresu i nieporządków. Do pewnego stopnia przypominało to proces opisywany przez teorię „wybitego okna” Wilsona i Kellinga (Sampson, Raudenbush 2005). Percepcja Pragi może być porównana do „czytania przestrzeni”, która jest stygmatyzowana, negatywnie nacechowana i oceniana gorzej w stosunku do otoczenia (Szczepański, Jałowiecki 2006). Co ciekawe, ta percepcja może się trochę zmienić, kiedy przestrzeń zostaje „oswojona” i staje się odpowiednia do codziennego życia. Widać to wyraźnie, kiedy analizuje się percepcję Pragi-Północ przez jej mieszkańców - zarówno tych, którzy są jej „starymi” mieszkańcami, jak i nowo przybyłymi. W naszych analizach położyliśmy szczególny nacisk na postrzeganie szeroko rozumianej różnorodności osiedla i sąsiadów jako użytkowników przestrzeni oraz ich wzajemnych relacji.

Ostatnie zmiany na Pradze-Północ, związane z napływem nowych mieszkańców, mają kilka wymiarów ${ }^{3}$. Niektórzy mieszkańcy narzekają na „generalną zgniliznę moralną" - głównie starsi i ci, którzy od dawna mieszkają na Pradze. Twierdzą oni, że zmiany są niekorzystne i są podejrzliwi wobec nowych sąsiadów: „Ci nowi ludzie mają pieniądze nie wiadomo skąd. Nie możesz sobie po prostu pozwolić na kupienie 100-metrowego mieszkania, kiedy masz dwadzieścia kilka lat”, mówi starsza kobieta (R31, kobieta, 83 lata, jednoosobowe gospodarstwo domowe, wykształcenie średnie). Wspomina $\mathrm{z}$ sentymentem wysoki status społeczny ludzi, z którymi żyła po wojnie i podkreśla, że każdy był „tutejszy”. Tylko nieliczne osoby z tej grupy uwa- żają nowo przybyłych mieszkańców za potencjalnie pozytywny czynnik. Najczęściej lepiej wyedukowani spośród „starych” mieszkańców wspominają o socjoekonomicznym aspekcie tych zmian: „Nowe prywatne budownictwo sprowadziło nowych, lepiej wykształconych ludzi.” (R17, mężczyzna, 65 lat, jednoosobowe gospodarstwo domowe, wyższe wykształcenie).

Bardzo nieliczni respondenci mają pozytywną opinię na temat gentryfikacji. Większość z nich zauważa zachodzące zmiany i coraz większą różnorodność społeczną. Jest ona czasem postrzegana jako potencjał, mogący przynieść pozytywną zmianę, ale częściej jako zagrożenie, mogące zburzyć „biedną ale stabilną” (Schaffner, Goldberg 2009) społeczność. Jednocześnie różnorodność jest wyzwaniem dla dalszego rozwoju i polityki lokalnej: „ciężko jest coś stworzyć przy takiej różnorodności. Jak nakłonić ludzi żeby działać dla wspólnego celu?" (R20, kobieta, 44 lata, samotny rodzic, średnie wykształcenie). „Starzy” mieszkańcy mówią często o podziale na „swoich” i „obcych”, szczególnie kiedy są pytani o kapitał kulturowy, wykształcenie i sytuację rodzinną. Bywają krytyczni wobec „nowych” mieszkańców, tworzących ogrodzone osiedla i kwestionują relacje między statusem socjoekonomicznym a wykształceniem, zauważając, że nie zawsze idą one w parze. „Nowi” mieszkańcy są świadomi, że wkraczają w konserwatywną społeczność, która jest jednak na ogół otwarta na tych, którzy zachowują się zgodnie z lokalnymi zasadami, oferując jednocześnie nowo przybyłym doświadczenie „prawdziwego świata”, które jest trudne do znalezienia gdzie indziej.

Mobilność społeczna jest procesem, który determinuje zmianę społeczeństwa w czasie. Jest dobrym wskaźnikiem kierunku, prędkości i głębokości zmian. Pokazuje, jak szybko społeczeństwo jest w stanie się dostosować do zmiany warunków zewnętrznych. Główne kategorie mobilności społecznej związane są z kierunkami (Sorokin 1927): mobilność pionowa, czyli zmiana pozycji w górę lub dół hierarchii (np. klasy lub stanu), i mobilność pozioma, tj. zmiana pozycji przy pozostaniu na tym samym poziomie w hierarchii względem innych. Główne kategorie mobilności związane z czasem jej trwania, to mobilność wewnątrzpokoleniowa - która ma miejsce w czasie trwania życia jednostki, oraz mobilność międzypokoleniowa - skupiająca się na różnicy pozycji między jednostkami z różnych pokoleń. Nasza analiza wykazała występowanie wszystkich tych kategorii, ale najczęściej obserwowana jest mobilność międzypokoleniowa. Mobil- 
ność społeczna jest czynnikiem, który rysuje mocną linię podziału między respondentami w badaniu.

Mobilność społeczna na Pradze-Północ różni się ze względu na trzy podstawowe czynniki: edukację, status ekonomiczny i długość zamieszkania. Mieszkańcy o wyższym dochodzie, lepiej wyedukowani oraz „nowi” na Pradze są bardziej mobilni pionowo, zarówno wewnątrz- jak i międzypokoleniowo. „Starzy” mieszkańcy i ci o wykształceniu zawodowym mają generalnie tendencję do utrzymywania stabilnej pozycji społecznej. Czasami podlegają mobilności poziomej, ale mają małe szanse poruszania się w górę hierarchii społecznej. Udaje się to jednak dzięki efektowi sąsiedztwa mniej zamożnym i starszym mieszkańcom o niższym wykształceniu.

Analiza wykazała także, że kluczową rolę dla mobilności społecznej odgrywają sieci społeczne. Ludzie z większą liczbą i różnorodnością słabych więzi społecznych są bardziej konkurencyjni na rynku pracy (Montgomery 1992). Reputacja dzielnicy ma niewielkie znaczenie dla jakości pracy, a sieć społeczna wykracza na ogół daleko poza obszar zamieszkania. W przypadku „starych” mieszkańców, o niższym wykształceniu i statusie socjoekonomicznym, silne więzi wewnątrz ich sieci społecznych (pomiędzy rodziną, przyjaciółmi, długo znanymi sąsiadami) są $\mathrm{w}$ wielu przypadkach niezbędne dla ich dalszej egzystencji i wspierają ich mobilność poziomą.

Można zatem podsumować, że różnorodność społeczna nie jest czynnikiem zwiększającym mobilność społeczną dzielnicy, ponieważ grupy mieszkańców o różnych statusach socjoekonomicznych i kapitale kulturowym rzadko wchodzą ze sobą w interakcję, przez co nie stają się elementami wzajemnych sieci społecznych. Można jednak założyć, że im silniejsza będzie integracja społeczna, wspierana przez aktywność władz miejskich, tym bardziej różnorodność będzie miała szansę pozytywnie wpłynąć na możliwości mobilności pionowej (w górę) tej części mieszańców, którzy mają najmniejsze szanse jej doświadczyć.

\section{WPŁYW HIPERRÓŻNORODNOŚCI I GENTRYFIKACJI NA ROZWÓJ EKONOMICZNY PRAGI-PÓŁNOC - WYNIKI BADAŃ DIVERCITIES}

Zgodnie z danymi z Rejestru Gospodarki Narodowej (REGON), na Pradze-Północ znajduje się 11080 przedsiębiorstw. Aż $96 \%$ z nich (10 587) to mikrofirmy, czyli takie, które zatrudniają mniej niż 10 pracowników, a ich roczny obrót nie przekracza równowartości $2 \mathrm{mln}$ euro. Pozostałe $4 \%$ to większe przedsiębiorstwa. Struktura wielkości firm pokazuje fragmentaryczność sektora prywatnego na Pradze-Północ, wyraźniejszą niż w innych dzielnicach mieszkalnych (Musterd, Andersson 2006). Struktura tej przedsiębiorczości ze względu na sektory działalności wygląda tak: ponad połowa firm należy do sektora cateringu i innych usług, a $25 \%$ to firmy sprzedaży hurtowej i detalicznej.

Niestety, dane uzyskane z Rejestru Gospodarki Narodowej nie mogą być agregowane na tak niskich poziomach, nie dostarczają więc szczegółowej informacji na poziomie poszczególnych osiedli. Przedsiębiorcy, którzy otworzyli swoje firmy na Pradze, na ogół dobrze wiedzą o zaletach i wadach tej lokalizacji. W zwią$\mathrm{zku} \mathrm{z}$ wymienioną fragmentacją sektora prywatnego otworzenie firmy jest relatywnie łatwe, ale jednocześnie trudno jest tu zdobyć stabilną i stałą klientelę. Praski klient jest niełatwy do zdefiniowania, a tym samym trudno jest skonstruować skuteczną kampanię marketingową. Jednocześnie skupianie strategii firmy na kliencie zewnętrznym jest tu znacznie bardziej ryzykowne. Ta sytuacja znajduje odbicie $\mathrm{w}$ danych z wywiadów. Przedsiębiorcy wydają się pewni siebie i jakości oferowanych usług lub towarów, ale są pełni obaw o przyszłość.

Zróżnicowanie przedsiębiorców, którzy brali udział w badaniu jest bardzo wyraźne w takich kategoriach, jak poziom wykształcenia, pochodzenie (na ogół z różnych części Polski) czy trajektorie życiowe. Mniej różnicuje ich wiek i pochodzenie etniczne.

Wielu badanych przedsiębiorców miało wyższe wykształcenie, które jednak nie pozwalało im znaleźć lepszego źródła zarobków. Jest to związane z wymaganiami na rynku pracy, które są niekompatybilne ze strukturą edukacji, w związku z czym wielu dobrze wykształconych ludzi jest zmuszonych do podejmowania nisko płatnych zawodów, niekoniecznie związanych z ich możliwościami. Własny biznes jest często traktowany jako forma wyjścia z takiej sytuacji, choć też nie zapewnia to możliwości czerpania zysków z nabytego wykształcenia. Zwykle prowadzenie przedsiębiorstwa nie wymaga wysokich kwalifikacji. W przypadku osób starszych posiadanie własnego przedsiębiorstwa jest często sposobem na zarobienie dodatkowych pieniędzy, żeby uzupełnić niskie emerytury.

Badani przedsiębiorcy $\mathrm{w}$ większości dobrze znają Pragę - nie tylko z opowieści lub lektury, lecz także z własnego doświadczenia, choć większość z nich żyje 
obecnie w innych dzielnicach. Co ciekawe, życie na Pradze lub poza nią niewiele wpływa na opinię przedsiębiorców na temat tej dzielnicy ani na temat możliwości prowadzenia w niej swojego biznesu. Respondenci owi działają przede wszystkim w sektorze usług (szczególnie cateringowych) i handlu, co odzwierciedla strukturę ekonomiczną Pragi. Jednak dzielnica ta słynie $\mathrm{z}$ tradycyjnego rzemiosła - lecz liczba czynnych zakładów stale spada. W ramach trwającego Zintegrowanego Programu Rewitalizacji, władze Warszawy planują kilka inicjatyw mających na celu wsparcie funkcjonowania tradycyjnych warsztatów rzemieślniczych na Starej Pradze. Jedną z rozważanych opcji jest stworzenie dla nich specjalnej enklawy na ulicy Małej.

[...] jest też ulica Mała, z budynkami, które są dość zniszczone, ale nadal bardzo ładne. Jest pomysł żeby zebrać tam biznes związany z tradycyjnym rzemieślnictwem i wytwórstwem, zorganizować deptak i sklepy na poziomie dolnym, wzdłuż ulicy. Władze miasta uważają, że byłby to dobry sposób na promocję praskiego tradycyjnego i mocno zagrożonego przemysłu. Ludzie z całej Warszawy mogliby tam przyjeżdżać wiedząc, że ta okolica specjalizuje się w tej dziedzinie, że można tu kupić różne produkty rzemieślnicze. (wywiad z P. Lisieckim, dawnym burmistrzem PragiPółnoc).

Wszystko wskazuje jednak na to, że ani takie inicjatywy, ani preferencyjne stawki wynajmu lokali nie odwrócą generalnego trendu spadku liczby rzemieślników zachodzącego głównie wskutek dużej dostępności niedrogich, masowo produkowanych dóbr. Zapotrzebowanie na naprawy i produkcję manualną jest coraz mniejsze. Brakuje też młodych ludzi zainteresowanych edukacją niezbędną do pracy w tym sektorze. Dlatego też, nawet gdyby zapotrzebowanie na tego typu usługi wzrosło, zabrakłoby wykwalifikowanych kadr. Wyniki naszych badań są w tej kwestii zbieżne z tym, jak J. Gardawski (2013) opisuje typowego rzemieślnika przywiązanego do swojej profesji i niechętnie się przebranżawiającego, nawet jeśli mogłoby to przynieść mu zyski.

Znaczna większość badanych przez nas przedsiębiorstw operuje w lokalach o niskim standardzie należących do miasta. Brakuje w nich ogrzewania, wentylacji, a czasem nawet dostępu do kanalizacji. Co ciekawe, ten niski standard lokali przyciąga drobną przedsiębiorczość na Pragę, ponieważ wiąże się on z niższymi cenami najmu. Stwarza to jednak nowe problemy, zwłaszcza dla przedsiębiorców oferujących usługi. Po pierwsze, trzyletnie umowy najmu zawiera- ne z miastem często nie są przedłużane, co zniechęca przedsiębiorców do inwestowania w lokale. Po drugie, podniesienie standardu lokalu może być bardzo trudne do wykonania. Wiele lokali mieści się w przedwojennych kamienicach i często podlega kontroli konserwatora zabytków. Wszystkie zmiany (zwłaszcza dotyczące wyglądu zewnętrznego), wymagają specjalnej zgody i użycia drogich materiałów. Jest to jeden z powodów, dla których ci z przedsiębiorców, którzy rozważają otworzenie nowego lokalu, chcą go otwierać w innej dzielnicy.

Co zaskakuje, istotna większość naszych respondentów wybrała lokalizację swojego przedsiębiorstwa przypadkowo. Pokazuje to pewną słabość przedsiębiorców, szczególnie właścicieli mikrofirm, którzy nie poprzedzili decyzji o otwarciu firmy analizą warunków lokalnego rynku. Jak należało się spodziewać, dla wielu przedsiębiorców istotnym czynnikiem lokacji był specyficzny „klimat” Pragi - szczególnie w początkowym stadium działania danego przedsiębiorstwa, gdy często stanowiło to element strategii marketingowej firmy. To podejście zostało jednak szybko porzucone jako nieefektywne. Niedługo po otworzeniu własnego biznesu okazywało się, że Praga jest dzięki swojej różnorodności dużo trudniejszym miejscem dla przedsiębiorców.

Wynagrodzenia na Pradze-Północ są nieznacznie niższe niż w innych dzielnicach Warszawy. Dzielnica charakteryzuje się też nieco większym poziomem bezrobocia niż otoczenie i to właśnie strach przed brakiem pracy był dla wielu przedsiębiorców motywacją do założenia tam biznesu. Rozpoczynając działalność, liczyli przede wszystkim na siebie, rodzinę i bliskich przyjaciół. Nieliczni, którzy wzięli pożyczkę z banku lub pomoc ze strony instytucji rządowych, robili to $\mathrm{z}$ dużą nieufnością. Sytuacja ta ilustruje siłę wiążącego kapitału społecznego w mocnych więzach, zwłaszcza rodzinnych, szczególnie $\mathrm{w}$ przypadku tradycyjnych dużych rodzin. Do pomocy zewnętrznej podchodzi się $\mathrm{z}$ rezerwą, widząc $\mathrm{w}$ niej częściej potencjalne zagrożenie, a nie szansę. Co ważne, tego typu strategie można obserwować nie tylko wśród polskich przedsiębiorców, lecz także wśród imigrantów, co w przypadku tych drugich jest dość zrozumiałe - czują się niepewnie w obliczu braku diaspory w kraju przyjmującym. W przypadku Polaków potwierdza to generalną niechęć i nieufność wobec instytucji rządowych.

Istnieje wiele publikacji na temat zależności między zróżnicowaniem społecznym w środowisku miejskim a wydajnością ekonomiczną danego obszaru lub jednostek i grup działających w jego obrębie. Choć 
wielu autorów wskazuje na negatywny wpływ heterogeniczności społecznej na wzrost gospodarczy (Easterly, Levine 1997, Alesina, La Ferrara 2005), niektórzy postrzegają różnorodność kulturową jako zasób, mogący podnieść produktywność (Bellin i i in. 2008) i ekonomiczną konkurencyjność okolicy (Eraydin, Tasan-Kok, Vranken 2010, Nathan 2011). Analizy wyników ekonomicznych przedsiębiorców na Pradze-Północ pozwalają jednoznacznie stwierdzić, że różnorodność społeczna dzielnicy i jej sytuacja ekonomiczna są ze sobą ściśle powiązane, oddziałując na siebie nawzajem zarówno pozytywnie, jak i negatywnie. Zróżnicowana i dynamiczna natura tej dzielnicy czyni z niej dobre miejsce dla osób kreatywnych, co może się okazać istotnym czynnikiem dla działających tutaj firm, choć badania wykazują, że na razie przedsiębiorcy nie uważają tego za istotny atut.

Praga-Północ jest dzielnicą, która w ostatnich latach uległa silnym przemianom. Zmiany te są stymulowane przez politykę miasta, a szczególnie przez realizację Zintegrowanego Programu Rewitalizacji, który przeznacza dużą część swoich funduszy na tę okolicę. Istotną rolę odgrywają także ogromne inwestycje prywatne - Centrum Praskie Koneser i Port Praski, nowoczesne kompleksy mieszkań, biur, budynków kulturowych oraz rozrywkowych. Od marca 2015 r. Praga jest połączona z lewobrzeżną Warszawą nową linią metra, co znacznie zmniejszyło korki na mostach. Wszystkie te zmiany sprawiają, że Praga (znana wcześniej jako „najbardziej niebezpieczna” część miasta) staje się „oswojona” i dostępna dla mieszkańców oraz turystów. Można się spodziewać, że gentryfikacja oraz usprawnienie transportu będzie miało pozytywny wpływ na sytuację praskich przedsiębiorców, zwiększając liczbę potencjalnych klientów i zmniejszając koszty potrzebne do zapewnienia sobie bezpieczeństwa. Trzeba jednak pamiętać, że poprawa transportu oznacza także łatwiejszy dojazd mieszkańców Pragi do innych dzielnic, a co za tym idzie - odpływ klientów, który, zdaniem naszych badanych, wystąpił na znacznie większą skalę niż napływ nowych.

Specyficzną cechą Pragi-Północ, z jej zróżnicowaną populacją, jest tworzenie potencjalnego miejsca dla rozwoju najróżniejszych gałęzi biznesu, oferując niemal każdemu okazję do znalezienia swojej „niszy” pośród tak różnorodnej klienteli. Jednocześnie jest jednak trudno przedstawić ofertę dla szerokiego spektrum klientów. Dlatego też Praga-Północ jest dzielnicą biznesu, stwarzającą korzystne warunki dla niewielkich przedsiębiorstw. Nie jest to jednak związane ze wspar- ciem dla drobnego przedsiębiorcy, lecz raczej z brakiem szans na wzrost firmy. Władze miasta zdają się zauważać ten problem, ale podejmowane przez nie inicjatywy, takie jak „Otwarta Ząbkowska” czy „Noc Pragi”, to stanowczo za mało, żeby rozwiązać problemy przedsiębiorców w tej dzielnicy. Tego typu wydarzenia mają charakter zbyt doraźny i tylko jednorazowo zwiększają przychód tutejszych firm.

Obraz Pragi jako miejsca rozpoczęcia biznesu nie jest zachęcający. Tutejsi przedsiębiorcy bardzo rzadko ze sobą współpracują, większość z nich dawno utraciła wiarę, że przyszłość może przynieść zmianę na lepsze. Dominuje poczucie beznadziei, a plany dotyczące przedsiębiorstw opierają się raczej na próbach przetrwania mimo ciężkiej sytuacji, niż próbach rozwoju. Wyjątkiem jest grupa artystów zrzeszona w ramach stowarzyszenia "Stan Rzeczywisty” zawiązanego w celu realizacji wspólnych celów, wzajemnej pomocy oraz zwiększenia swojej siły $\mathrm{w}$ kontaktach $\mathrm{z}$ instytucjami władzy.

Mimo złego ogólnego stanu lokalnej przedsiębiorczości, zdarzają się firmy będące przykładem sukcesu ekonomicznego, jednak na ogół są to biznesy nastawione na klienta spoza Pragi. Firmy te rozszerzają swoją ofertę na klientów z całego kraju, a często także prowadzą operacje międzynarodowe.

Ostatnie trendy związane z rozwojem Pragi-Północ wydają się mieć daleko większy wpływ na mieszkańców, niż na okolicznych przedsiębiorców. Ci drudzy nie czują żadnych pozytywnych zmian związanych $\mathrm{z}$ rewitalizacją dzielnicy. Jest to o tyle niezaskakujące, że Zintegrowany Program Rewitalizacji jest skierowany głównie na regenerację tkanki miejskiej w jej fizycznym i społecznym wymiarze. Otwarcie dwóch stacji metra na Pradze, zamiast dostarczyć klientów do praskich biznesów, pomogło mieszkańcom Pragi wygodnie korzystać z usług firm z innych części Warszawy.

\section{WNIOSKI}

Gentryfikacja jest procesem zwiększającym różnorodność społeczną. Oba te zjawiska mają wielowymiarowy wpływ na rzeczywistość społeczną, w której występują. W naszych analizach skupiliśmy się na ich znaczeniu dla mobilności społecznej i przedsiębiorczości, na przykładzie najbardziej różnorodnej dzielnicy najbardziej różnorodnego miasta w Polsce, czyli warszawskiej Pragi-Północ. 
Różnorodność społeczna ma duży potencjał zmiany mobilności społecznej w gentryfikujących się dzielnicach. Napływająca ludność o wyższym statusie socjoekonomicznym i wykształceniu ma szanse stymulować mobilność pionową ludności autochtonicznej. Żeby to się jednak stało, muszą się wytworzyć choćby słabe więzi między sieciami społecznymi tych dwojga grup. Tymczasem na Pradze-Północ dochodzi do ich separacji, życia „obok siebie”, do wzajemnej niechęci i nieufności. Możliwe, że potencjał leżący w różnorodności społecznej mógłby być uruchomiony przez odpowiednią politykę miasta i dzielnicy oraz realizowanie programów integracji jej mieszkańców.

Różnorodność społeczna dzielnicy ma dwojaki wpływ na przedsiębiorczość. Z jednej strony ułatwia tworzenie nowych firm, ponieważ dzięki dużej różnorodności klientów łatwiej jest znaleźć swoją niszę i osoby zainteresowane oferowanymi usługami bądź produktami. Z drugiej strony ta fragmentaryczność powoduje, że można pozyskać tu dużą, stabilną grupę stałych klientów i odpowiedzieć na potrzeby większej grupy mieszkańców. Z tych powodów Praga-Północ jest zdominowana przez mikrofirmy, które nie mają realnych szans na rozwój. Działania władz miasta skierowane na rozwój praskiej przedsiębiorczości są zbyt efemeryczne, żeby przynieść zauważalny rezultat. Dodatkowo różnorodność społeczna i wspomniany brak integracji skutkuje brakiem zaufania, (także wśród przedsiębiorców), przez co bardzo rzadko współpracują oni ze sobą i próbują tworzyć coś razem dla wspólnego dobra. Wyjątkiem są tutaj artyści, grupa kreatywna, która zjednoczyła się dla wspólnego celu. Możliwe, że będą oni pionierami zmiany w stosunkach społecznych między przedsiębiorcami na Pradze-Północ.

\section{PRZYPISY}

${ }^{1}$ Governing Urban Diversity: Creating Social Cohesion, Social Mobility and Economic Performance in Today's Hyper-diversified Cities, gdzie w ramach komponentu 6. zostało zrealizowanych 50 wywiadów pogłębionych $\mathrm{z}$ mieszkańcami, zaś $\mathrm{w}$ ramach komponentu 7. 40 wywiadów pogłębionych z przedsiębiorcami z Pragi-Północ.

${ }^{2}$ Spośród wszystkich cudzoziemców, którzy otrzymali pozwolenie na pracę w Polsce w 2011 r. (40 808 osób), 55\% jest zarejestrowanych w Warszawie (Rocznik statystyczny 2012, s. 174) . Odsetki konkretnych grup migranckich bywają dużo wyższe. Na przykład 85\% spośród zarejestrowanych w Polsce Wietnamczyków mieszka w Warszawie (Rządowa Rada Ludnościowa 2012, s. 186). Warszawa przyciąga także nieproporcjonalnie dużą część migrantów przybywających do Polski z krajów UE oraz studentów zagranicznych z różnych państw.
${ }^{3}$ Jest też kilka pozytywnych refleksji na temat przedwojennej Pragi, która była miejscem bardzo zróżnicowanym, wielojęzykowym i wielokulturowym, z dużym udziałem mniejszości żydowskiej.

\section{BIBLIOGRAFIA}

Alesina A., La Ferrara E., 2005, Ethnic diversity and economic performance, „Journal of Economic Literature”, 43, s. 762-800.

Angrist J., Kugler A., 2003, Protective or counter-protective? Labor market institutions and the effect of immigration on $E U$ natives, „Economic Journal”, 113 (488), s. 302-331.

Badyina A., Golubchikov O., 2005, Gentrification in central Moscow: A market process or a deliberate policy? Money, power and people in housing regeneration in Ostozhenka, Moscow.

Bauman Z., 2000, Liquid modernity, Polity Press, Malden.

Bellini E., Ottaviano G.I.P., Pinelli D., Prarolo G., 2008, Cultural diversity and economic performance: Evidence from European regions, Hamburg Institute of International Economics, Hamburg.

Bodaar A., Rath J., 2005, Cities, diversity and public space, „Metropolis World Bulletin", 5, s. 3-5.

Bolt G., Kempen van R., 2013, Neighbourhood based policies in The Netherlands: counteracting neighbourhood effects?, [w:] D. Manley, M. van Ham, N. Bailey, L. Simpson, D. Maclennan (eds.), Neighbourhood effects or neighbourhood based problems?, Springer, Dordrecht, s. 195-213.

Bourdieu P., Wacquant L.J.D., 1992, An invitation to reflective sociology, University of Chicago Press, Chicago, s. 119

Brännström L., Rojas Y., 2012, Rethinking the long-term consequences of growing up in a disadvantaged neighbourhood: lessons from Sweden, „Housing Studies”, 27 (6), s. 729-747.

Bridge G., Watson S., 2013, Reflections on division and difference, [w:] G. Bridge, S. Watson S. (eds.), The New Blackwell Companion to the City, Wiley Blackwell, Chichester.

Cantle T., 2012, Interculturalism: for the era of globalisation, cohesion and diversity, „Political Insight”, 3 (3), s. 38-41.

Cully M., 2009), Diversity dividend: Making the most from cultural diversity, Australian Government, Department of Immigration and Citizenship, Sydney.

Davidson M., Lees L., 2005, New built 'gentryfication' in London's Riverside Renaissance, „Environment and Planning”, A 37(7), s. $1165-1190$.

Derek M., Duda-Gromada K., Kosowska P., Kowalczyk A., Madurowicz M., 2013, Problemowe i problematyczne abc turystyki w Warszawie, „Prace Geograficzne”, 134, s. 7-36

Easterly W., Levine R., 1997, Africa's growth tragedy: Policies and ethnic divisions, „Quarterly Journal of Economics”, 112(4); http://ssrn.com/abstract=88828.

Eraydin A., Tasan-Kok T., Vranken J., 2010, Diversity matters: Immigrant entrepreneurship and contribution of different forms of social integration in economic performance of cities, „European Planning Studies”, 18, s. 521-543.

Fainstein S., 2005, Cities and diversity: should we want it? Can we plan for it?, „Urban Affairs Review”, 41, s. 3-19.

Faist T., 2009, Diversity: a new mode of incorporation?, „Ethnic and Racial Studies", 32 (1), s. 171-190.

Friedrichs J., 1998, Do poor neighbourhoods make their residents poorer? Context effects of poverty neighbourhoods on residents, [w:] H.J. Andress (ed.), Empirical poverty research in a comparative perspective, Ashgate, Aldershot, s. 77-99. 
Galster G., 2008, Quantifying the effect of neighbourhood on individuals: Challenges, alternative approaches, and promising directions, „Schmollers Jahrbuch”, 128, s. 1-42.

Gardawski J., 2013, Rzemieślnicy i biznesmeni. Właściciele małych $i$ średnich przedsiębiorstw prywatnych, Wyd. Naukowa Scholar, Warszawa.

Gordon I.R., Monastiriotis V., 2006, Urban size, spatial segregation and inequality in educational outcomes, „Urban Studies”, 43 (1), s. 213-36.

Grabkowska M., 2012, Regeneration of the post-socialist inner city: Social change and Bottom-up transformation in Gdańsk, Pracownia, Gdańsk.

Granovetter M.S., 1973, The strength of weak ties, „American Journal of Sociology", 78, 6, s. 1360-1380.

Gusfield J.R., 1975, Community: A critical response, Harper \& Row, New York.

Kempen van R., Wissink B., 2014, Between spaces and flows: towards a new agenda for neighbourhood research in an age of mobility, „Geografiska Annaler”, ser. B, 96 (2), s. 95-108.

Kleinhans R., 2005, Sociale Implicaties van Herstructurering en Herhuisvesting, Delft University Press, Delft.

Korcelli P., Korcelli-Olejniczak E., 2005, Warsaw: An evaluation of population trends and forecasts. Regional Scientists' Tribute to Professor Ryszard Domański, „Studia Regionalia”, 15, s. 243-257.

Korcelli-Olejniczak E., 2014, Partycypacja nauki $i$ jej instytucji w kształtowaniu przestrzeni miasta, [w:] T. Markowski, D. Stawasz (eds.), Partnerstwo i odpowiedzialność w funkcjonowaniu miasta, KPZK PAN, Warszawa, s. 52-63.

Korcelli-Olejniczak E., Piotrowski F., 2015, Hiperróżnorodność w mieście - znaczenie, wyzwanie, zasób, [w:] A. Wolaniuk (red.), Współczesne czynniki i bariery rozwoju miast, XXVII „Konwersatorium Wiedzy o Mieście”, Wyd. Uniwersytetu Łódzkiego, Łódź.

Korcelli-Olejniczak E., Bierzyński A., Dworzański P., Piotrowski F., 2016, Fieldwork entrepreneurs, Warsaw (Poland); https://www. urbandivercities.eu/wp-content/uploads/2016/09/WP7-Warsaw -Report-2N-Fieldwork-Entrepreneurs.pdf.

Korcelli-Olejniczak E., Bierzyński A., Dworzański P., Grochowski M., Piotrowski F., Węcławowicz G., 2017, Dealing with urban diversity. The case of Warsaw, IGSO PAS, Warsaw.

Kovács Z., Wiesner R., Zischner R., 2013, Urban renewal in the inner-city of Budapest: Gentrification from a post-socialist perspective, „Urban Studies”, 1, s. 22-38.

Bank Danych Lokalnych, 2015, GUS, Warszawa.

Łukasiuk M., 2007, Obcy w mieście: migracja do współczesnej Warszawy, Żak, Warszawa.

Miasta otwarte - raport, 2015, Fundacja Inna Przestrzeń, ss. 194.

Montgomery J., 1992, Job search and network composition: implications of the strength-of-ties hypothesis, „American Sociological Review", 57, s. 586-596.

Musterd S., Andersson R., 2006, Employment, social mobility and neighbourhood effects: The case of Sweden, „International Journal of Urban and Regional Research", 30, 1, s. 120-140.

Nathan M., 2011, Ethnic inventors, diversity and innovation in the UK: evidence from patents microdata, Spatial Economics Research Centre, discussion paper no. SERCDP0092, October, Spatial Economics Research Centre London.

Putnam R.D., 2001, Community-based social capital and educational performance, [w:] D. Ravitch, J.P. Viteritti (eds.), Making good citizens, education and civil society, Yale University Press, New Haven, s. 58-95.
Ranking dzielnic, 2013, Ranking dzielnic Warszawy pod względem atrakcyjności warunków życia, Urząd Statystyczny w Warszawie, Mazowiecki Ośrodek Badań Regionalnych, Warszawa.

Rocznik statystyczny. 2012, 2013, Główny Urząd Statystyczny, Warszawa, ss. 174.

Rocznik statystyczny Warszawy, 2012, http://warszawa.stat.gov.pl/ publikacje-i-foldery/roczniki-statystyczne/rocznik-statystycznywarszawy-2012,6,2.html; 25.06.2016.

Rządowa Rada Ludnościowa, 2013. Założenia polityki ludnościowej Polski. Projekt, Warszawa.

Sammartino A., 2001, Using diversity climate surveys: A toolkit for diversity management. Programme for the Practice of Diversity Management by Department of Immigration and Multicultural Affairs (DIMA) and Australian Centre for International Business (ACIB).

Sampson R.J., Raudenbush S.W., 2005, Neighborhood stigma and the perception of disorder, http://scholar.harvard.edu/files/ sampson/files/2005_focus_raudenbush.pdf; 25.06.2016.

Schaffner G., Goldberg G.S., 2009, Poor women in rich countries, Oxford University Press, New York.

Sorokin P.A., 1927, Social and cultural mobility, Free Press, Glencoe.

Stępniak M., Węcławowicz G., Górczyńska M., Bierzyński A., 2009, Atlas Warszawy, 11: Warszawa w świetle Narodowego Spisu Powszechnego 2002, IGiPZ PAN, Warszawa.

Syrett S., Sepulveda L., 2011, Realising the diversity dividend: Population diversity and urban economic development, ,Environment and Planning" A, 43, s. 487-504.

Szczepański M., Jałowiecki B., 2006, Miasto i przestrzeń w perspektywie socjologicznej. Wykłady z socjologii, 4, Wyd. Naukowe Scholar, Warszawa.

Tasan-Kok T., Kempen van R., Raco M., Bolt G., 2014, Towards hyper-diversified European cities. A critical literature review, Utrecht University, The Netherlands.

Tasan-Kok T., Vranken J., 2008, From survival to competition? The socio-spatial evolution of immigrant entrepreneurs in Antwerp, [w:] P. Ache, H.T. Andersen, T. Maloutas, M. Raco, T. TaşanKok (eds.), Cities between competitiveness and cohesion: Discourses, realities and implementation, Springer, Amsterdam, s. $151-168$.

Urban S., 2009), Is the neighbourhood effect an economic or an immigrant issue? A study of the importance of the childhood neighbourhood for future integration into the labour market, „Urban Studies”, 46 (3), s. 583-603.

Vertovec S., 2010, Towards post-multiculturalism? Changing communities, conditions and contexts of diversity, „International Social Science Journal", 61 (199), s. 83-95.

Vertovec S., 2007, Super-diversity and its implications, „Ethnic and Racial Studies", 30 (6), s. 1024-1054.

Węcławowicz G., 2001, Przestrzeń ubóstwa - nowy czy stary wymiar zróżnicowania przestrzenno-społecznego $w$ miastach Polski, „Przegląd Geograficzny”, 73(4), s. 451-475.

Zelinsky W., Lee B.A., 1998, Heterolocalism: an alternative model of the socialspatial behaviour of immigrant ethnic communities, „International Journal of Population Geography”, 4 (4), s. 281298.

Artykuł wpłynął:

7 czerwca 2016

Zaakceptowano do druku:

8 września 2016 